\title{
Productivity in Building Construction
}

\author{
Eng. Varma Santosh*, Prof. M. R. Apte** \\ *M. E Civil [C \& M] MIT College, Pune. E-mail id-sntshvrma@gmail.com \\ ** Guide \& Professors of Civil Eng. Dept., MIT College, Pune.
}

\begin{abstract}
Productivity has for many years been an issue for the construction site. This paper reviews current productivity measurement literature, particularly that pertaining on the construction site, and offers recommendations/suggestions, for improvement of productivity at the site. It also shows that productivity can be measured by monthly planned/targeted concrete and actual consumption of concrete data. Whereas targeted concrete is the input value and actual consumption of concrete is the output of the productivity. Considering single factor type of productivity i.e. concrete we have calculated the productivity for shell and core type of contract. It also show few reasons, why productivity at construction site is reduced due to improper shuttering, reinforcement activity.
\end{abstract}

\section{Introduction}

Productivity is one of the most important factors affecting the overall performance of any construction site, large or small. There is no standard way to define productivity for construction operations. In general terms, construction productivity can be simply illustrated by an association between an output and an input. As such it would be worthwhile to study various quantitative methods, including construction productivity measurements for reason of:

i. Decreased total cost and duration of production.

ii. Improved quality.

iii. Providing management with an effective tool to direct and control the productivity performance of a construction site.

iv. Offering feedback to employees on their productivity performance.

v. Creating the basis for sharing the gains of higher productivity.

Productivity measurement at construction site level enables companies to monitor their own performance against their site performance. Construction productivity at construction site level can be grouped under various departments likes, productivity in concrete, steel work and shuttering.

\section{Review of international literature}

In construction, higher productivity means seeing the final result sooner, which in turn creates satisfaction. Borcherding and Oglesby [1975] reported that job dissatisfaction can be one factor that will increase costs, produce time delays and generally reduce productivity on most types of projects. One way that construction management can influence productivity is by determining how smooth the work will flow and how much work can be accomplished. Another more important way that construction management influences productivity is by how it influence worker's attitude, which is a major element in worker motivation and determining how much work will be accomplished.

Productivity in the construction industry in Indonesia is not only influenced by labour, but also by other factors such as equipment, materials, construction methods, and site management Arditi and Mochtar, [2000].

Construction productivity can be analyzed at industry, firm, project, and activity/task levelHuang et al. [2009], and the relations between measures for aggregate and activity levels are complicated Goodrum et al. [2002]. Given that there are differences between concepts of productivity and between uses of productivity, depending on the level, it is hardly meaningful to claim that there is asingle meaning of construction productivity, except that the term refers to an output/input ratio.

Mr. James D. Whiteside, II, PE explains that Productivity is the average direct labor hours to install a unit of material. In a perfect world, perfect productivity [1.0] would be accomplished in a 48-hour work week, with everyone taking all of their holidays and vacation days as planned. All of the engineering drawings would be 100 percent complete, there would be no delays of any kind, everyone would work safely, everything would 
fit perfectly the first time, the weather would be 70 degrees Fahrenheit, and there would be no litigation at the end of the project.

Many authors have linked productivity very closely to quality and quality management. Edosomwan (1987) defined productivity and quality management as an integrated process involving both management and employees with the ultimate goal of managing the design, development, production and use of various types of products or services in both the work environment and market place.

In this study, the following objectives are envisaged.

1. Study the productivity concept for the construction site.

2. Measuring the productivity of the construction site.

3. Provide Suggestion to increase productivity of the same.

Here below we are mention few points of formwork and reinforcement productivity which ultimately affect the productivity of total concrete.

\section{Formwork Productivity}

The variability of productivity in formwork operation is very wide due to the nature of its works and the increasing diversity of construction methods that can be used. In addition to the usual factors affecting productivity, there are few factors which are directly influence formwork productivity.

\section{i. Floor Layout}

The type of floor system can greatly influence the productivity of form work. Flat slab systems require less work than beam-and-slab systems and make buildings more buildable, thereby enhancing productivity. The floor layout with beam and sunken toilet slab in residential building require special formwork specification for those purpose which result lightly reduction in productivity. This does not happen in flat slab.

\section{ii. Formwork System}

There are several formwork systems that can be used for different projects. However, there are two broad categories, namely.

a. Proprietary or commercial system formwork.

i. MIVAN formwork

ii. Steel formwork

b. Conventional formwork, fabricated on site.

i. Ply wood formwork

\section{iii. Equipment}

Methods of moving formwork on sites have changed with improvements in lifting equipment [like cranes, material lift etc.] and these have resulted in more economic use of materials and reduction in labour. Generally, the positive impact of equipment and lifting facilities on productivity lies in the possibility of handling larger panels or materials in less time, which give rise to higher rate of output.

\section{Reinforcement Productivity}

The two main steel reinforcement bar types are mild steel \& high yield strength steel bars and the length of bars normally supplied is 12 meters.

Steel bars supplied to construction sites should be usually pre-cut and bent as per specification required for specific item of work. In fact many constructions site has adopted this practice. This practice simplifies the work to be done on site. In reinforcement installation, the degree of congestion and the bar spacing adversely affect productivity. With congested reinforcement, the steel installation becomes more complex and obviously will require more time to perform. Someof thefactorsthat affect productivity ofreinforcement are as following.

\section{i. Steel reinforcement quantity}

The adequate quantity of steel reinforcement present in a concrete member tends to have a direct impact on productivity. Advance storage of diameter \& length of bars of adequate quantities should to be stored on the site, for carrying out in advance cut\& bend operations. 


\section{ii. Design Arrangement of Bars}

Productivity will tend to drop as the level of difficulty arises due to the lower output of the steel fixer when a particular design presents a complex arrangement of the reinforcing bars. Where there is no flat slab construction.

\section{iii. Presence of Bent up bars}

Straight bars are easier to detail, supply and install than bars with bends. Hence the total number of bends within a member may have a significant impact on productivity. Obviously some structural members have more bent bars than others because of their physical features and structural function.

\section{Productivity In Concrete}

Concrete and concreting have generated great interest in the construction industry. Much research has been done in the field of concrete technology, much more than in formwork and steel reinforcement technology. However, most of the research is on concrete materials and techniques in the manufacture of concrete, with little research on the productivity aspects of concreting on the construction site. The Productivity of concreting operations will, to a large extent, depend on the following.

i. Methods of supply of concrete, including delivery times and intervals.

ii. The shape and size of the structural member, since the ease or difficulty of pouring fresh concrete will depend not only on the state of the fresh concrete \& the presence of steel reinforcement, but also on the shape and dimensions of the concrete member \& levels.

iii. The availability of machinery such as concrete mixers, batching plant, transit mixer, concrete pumps and tower cranes etc. They can determine the speed at which concreting can progress. This makes direct impact on productivity of concrete.

iv. The presence of steel reinforcement, as the numbers, size and spacing of the bars can affect the pouring and proper compaction of fresh concrete.

v. The weather conditions on the day of concreting, as work can be affected by rains or cyclones.

1. Single factor productivity.

\section{Type of Productivity}

Productivity calculated for single activity like labour, concrete or equipment is known as single factor productivity.

\section{Multi factor productivity.}

Productivity calculated for more than one activity like labour and equipment or Material, labour \& equipment and concrete is called multi factor productivity.

\section{Total Factor productivity.}

Productivity calculations which include all the activity on the construction site is called as total factor productivity.

In this paper we are taken into consideration only single factor productivity for concrete during the construction.

\section{Data Collected for productivity.}

a. Detail Planning of the project for concrete work

b. Monthly Actual Consumption of Concrete.

c. Delay data collection analysis Reports from $1^{\text {st }}$ Jan 2013 till month of $31^{\text {st }}$ July 2103.

d. Monthly Certified Bills.

After data is collected we went for analyzing the collected data for productivity and find out the productivity of a construction site and provide with a proper suggestion to eliminate the error in the process of certain activity and increase the same.

\section{Measurement of productivity}

Productivity for individual projects can be measured upon project completion or during construction. Productivity can be calculated on a monthly basis by estimating the floor area completed at the end of each month and dividing this figure by the total manpower used for that month. 
Building Productivity =

$\%$ of building

Completed per month $=$

\section{Gross Floor Area}

Total Manpower

Monthly payment certified

Total Contract Sum

This equation is usedbythe Construction Industry Development Board [CIDB] Singaporetocompute the monthlyproductivityfiguresof Individualprojects. However productivity can be simply illustrated by an association between an output and an input. The Input and Output values are Targeted Quantity and Achieve Quantity for period of a month. Bye computing [Input/Output] industry can find out the productivity value in percentage. As it is easy to compute this formula is generally used to calculate the single factor productivity for any kind of activity whose input and output value are known.

$$
\text { Productivity }=\frac{\text { Input }}{\text { Output }}
$$

\section{Methodology and Case Study}

In order to achieve the objective, data was collected from the field practices. This case study is a multistorey seven number of public residential building with total of 514 flats at Pune [Project Phase 1 of 3]. It is 'Shell and core type of contract which means referring to the main structure and structural steel work and not inclusive of interior finishes and waterproofing. Shell and Core are type of building design is to speed up the whole design \& build process. Cores are pertaining to structures, vertical transportation systems while Shell is facade and both are those long lead items for the constructions.

1. Joshi \& Modi Construction [JMC]

2. Type of contract 'Shell and core'.

3. Total cost of contract65.73 cores.

4. Duration of contract 24 months.

5. Start Date of project $3^{\text {rd }}$ of December 2012.

All the buildings for the project are built of cast-in-situ reinforced concrete frame structure. The external \& internal walls are in reinforced concrete executed in Mivan Shuttering. The traditional Conventional formwork is generally used for Sub Structural work, together with metal scaffolding and props. The project is already behind the planned schedule by 3 months.

\section{Data collected for concrete work for period of seven months.}

[1 $1^{\text {st }}$ January 2013 to $31^{\text {st }}$ July 2013]

Below Table 1.1 shows Planned and Executed quantity of the major activity like Shuttering, Reinforcement and Concrete from January 2013 till July 2013.

Table 1.1 Planned and Executed quantity of Major Activity

\begin{tabular}{|c|c|c|c|c|c|c|c|}
\hline \multirow{2}{*}{$\begin{array}{l}\text { Sr. } \\
\text { No. }\end{array}$} & \multirow{2}{*}{$\begin{array}{l}\text { Month \& } \\
\text { Year }\end{array}$} & \multicolumn{2}{|c|}{ Shuttering in 'Sqm' } & \multicolumn{2}{|c|}{ Reinforcement in ' $T$ ' } & \multicolumn{2}{|c|}{ Concrete in 'Cum' } \\
\hline & & Planned & Executed & Planned & Executed & Planned & Executed \\
\hline 1 & Jan-13 & $4,663.00$ & $2,402.56$ & 216.62 & 215.28 & $1,050.00$ & 541.00 \\
\hline 2 & Feb-13 & $12,790.00$ & $1,808.78$ & 421.30 & 378.71 & $2,518.00$ & 356.10 \\
\hline 3 & Mar-13 & $20,643.00$ & $6,373.33$ & 635.18 & 602.84 & $2,731.00$ & 843.17 \\
\hline 4 & Apr-13 & $21,980.00$ & $6,026.12$ & 780.68 & 539.81 & $2,649.00$ & 726.26 \\
\hline 5 & May-13 & $27,558.00$ & $7,963.10$ & 891.92 & 567.32 & $3,070.00$ & 887.10 \\
\hline 6 & Jun-13 & $31,054.00$ & $6,707.66$ & $1,029.20$ & 595.24 & $3,400.00$ & 734.40 \\
\hline 7 & Jul-13 & $26,915.00$ & $5,238.95$ & $1,120.00$ & 607.53 & $3,139.00$ & 611.00 \\
\hline
\end{tabular}

As it is Shell and core type of contract concrete make major impact on the project and productivity of the project. Considering single factor productivity we have analyzed concrete activity to find out the value of productivity. 
The Planned Monthly Turnover and planned monthly concrete for the project construction are shown in the table 1.1 belowfrom January 2013 to July 2013.

Table 1.2 - Monthly Planned Progress of Project.

\begin{tabular}{|l|l|l|l|l|}
\hline $\begin{array}{l}\text { Sr. } \\
\text { No. }\end{array}$ & $\begin{array}{l}\text { Month \& } \\
\text { Year }\end{array}$ & $\begin{array}{l}\text { Planned Total Monthly } \\
\text { Turnover in Lakh. }\end{array}$ & $\begin{array}{l}\text { Planned } \\
\text { Concrete [Cum] }\end{array}$ & $\begin{array}{l}\text { Turnover for Concrete } \\
\text { In Lakh. }\end{array}$ \\
\hline 1 & Jan-13 & 194.25 & 1050.00 & 065.10 \\
\hline 2 & Feb-13 & 465.83 & 2518.00 & 156.11 \\
\hline 3 & Mar-13 & 505.24 & 2731.00 & 169.32 \\
\hline 4 & Apr-13 & 490.07 & 2649.00 & 164.23 \\
\hline 5 & May-13 & 567.95 & 3070.00 & 190.34 \\
\hline 6 & Jun-13 & 629.00 & 3400.00 & 210.80 \\
\hline 7 & Jul-13 & 580.72 & 3139.00 & 194.61 \\
\hline
\end{tabular}

Actual Executed Monthly Turnover and Executed Monthly Concrete for the project construction are shown in the table 1.3 below from January 2013 to July 2013.

Table 1.3 - Monthly Actual Progress of Project.

\begin{tabular}{|l|l|l|l|l|}
\hline $\begin{array}{l}\text { Sr. } \\
\text { No. }\end{array}$ & $\begin{array}{l}\text { Month \& } \\
\text { Year }\end{array}$ & $\begin{array}{l}\text { Actual Total Monthly } \\
\text { Turnover in Lakh. }\end{array}$ & $\begin{array}{l}\text { Executed } \\
\text { Concrete [Cum] }\end{array}$ & $\begin{array}{l}\text { Actual Turnover } \\
\text { forConcreteIn Lakh. }\end{array}$ \\
\hline 1 & Jan-13 & 100.09 & 541.00 & 33.54 \\
\hline 2 & Feb-13 & 65.88 & 356.10 & 22.08 \\
\hline 3 & Mar-13 & 155.99 & 843.17 & 52.28 \\
\hline 4 & Apr-13 & 134.36 & 726.26 & 45.03 \\
\hline 5 & May-13 & 164.11 & 887.10 & 55.00 \\
\hline 6 & Jun-13 & 135.86 & 734.40 & 45.53 \\
\hline 7 & Jul-13 & 113.04 & 541.00 & 33.54 \\
\hline
\end{tabular}

Graph 1.1 Shows comparison between Monthly Planned Turnover and Monthly Actual Turnover achieve for the project during construction form January 2013 to July 2013.

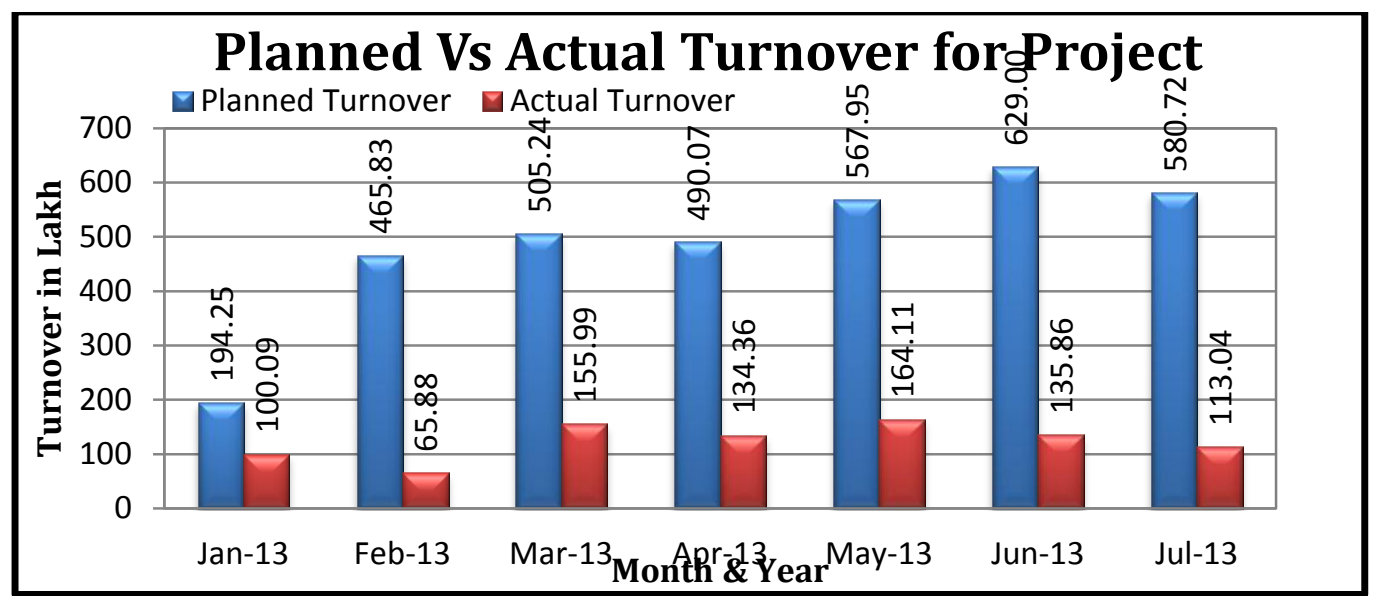

Graph 1.1 - Monthly Planned Total turnover Vs. Actual turnover for Project.

Graph 1.2 Shows comparison between Monthly Planned Turnover for Concrete and Monthly Actual Turnover for concrete achieve for the project during construction form January 2013 to July 2013. 


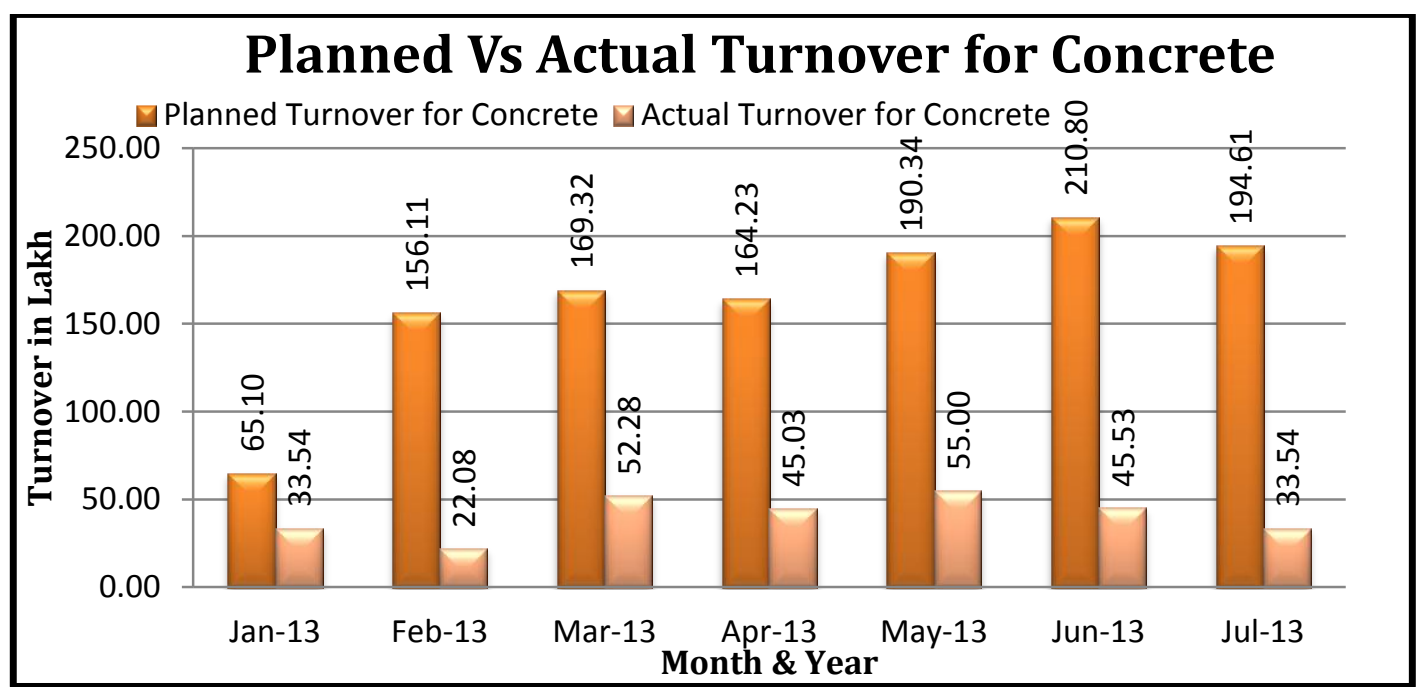

Graph 1.2 - Planned Total turnover for Concrete Vs. Actual Turnover for concrete.

Graph 1.3 Shows comparison between Monthly Planned Quantity of Concrete and Monthly Actual achieved quantity of concrete for the project during construction form January 2013 to July 2013.

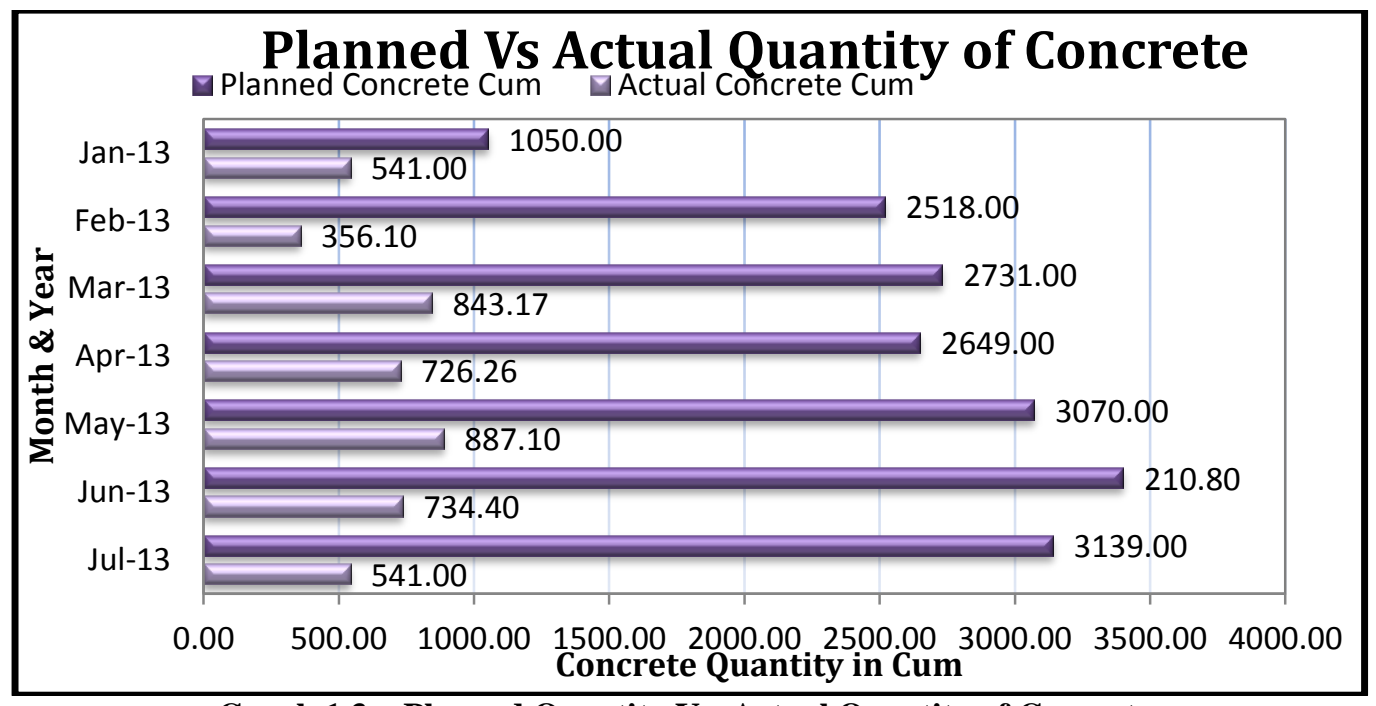

Graph 1.3 - Planned Quantity Vs. Actual Quantity of Concrete.

Following table 1.4 explain the difference between planned Quantity of Concrete and Actual quantity of concrete for project construction. As Project was supposed to be completed 52.22\% till the month of $31^{\text {st }}$ July 2013 but due low productivity and insufficient availability of resources only $13.22 \%$ of project was executed during this time period. The following table shows the project productivity calculation.

\begin{tabular}{|l|l|l|l|l|l|}
\hline $\begin{array}{l}\text { Month \&ear } \\
\text { Y }\end{array}$ & $\begin{array}{l}\text { Planned } \\
\text { Concrete } \\
\text { (Cum) }\end{array}$ & $\begin{array}{l}\text { Planned } \\
\text { Cumulative }\end{array}$ & $\begin{array}{l}\text { Executed } \\
\text { Concrete } \\
\text { (Cum) }\end{array}$ & $\begin{array}{l}\text { Executed } \\
\text { Cumulative }\end{array}$ & $\begin{array}{l}\text { Productivity } \\
\text { in \% }\end{array}$ \\
\hline & A & B & C & D & D/B \\
\hline Jan-13 & 1050.00 & 1050.00 & 541.00 & 541.00 & $51.52 \%$ \\
\hline Feb-13 & 2518.00 & 3568.00 & 356.10 & 897.10 & $29.64 \%$ \\
\hline Mar-13 & 2731.00 & 6299.00 & 843.17 & 1740.27 & $32.22 \%$ \\
\hline Apr-13 & 2649.00 & 8948.00 & 726.26 & 2466.53 & $34.22 \%$ \\
\hline May-13 & 3070.00 & 12018.00 & 887.10 & 3353.63 & $35.11 \%$ \\
\hline Jun-13 & 3400.00 & 15418.00 & 734.40 & 4088.03 & $33.89 \%$ \\
\hline Jul-13 & 3139.00 & 18557.00 & 611.00 & 4699.03 & $32.48 \%$ \\
\hline
\end{tabular}

Table 1.4 Productivity Calculations

As we can observe that productivity of the project was only $32.48 \%$ in the month of July 2013 . The graph 1.4 below shows thehuge differences between monthly planned actual executed quantities of the concrete. 


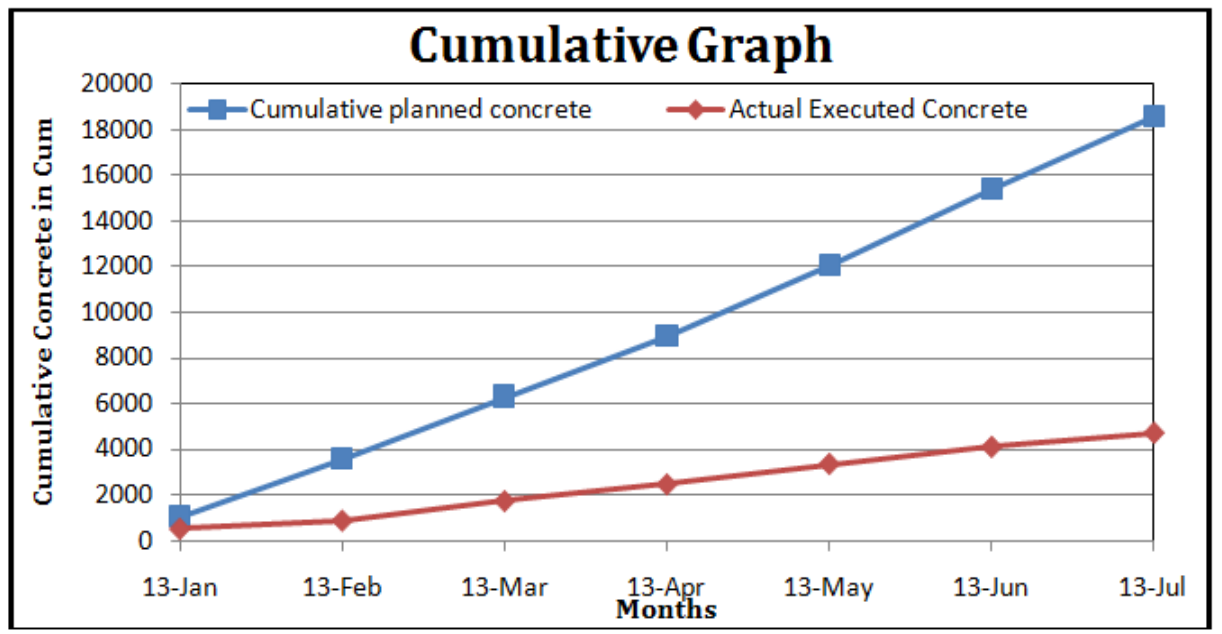

Graph 1.4 - Cumulative differences between planned \& actual quantity of concrete.

Above data explain that from the beginning of the project it was unable to achieve the planned/targeted quantity of the production and the difference goes on increasing due low productivity.

As it is shell and core type of contract and concrete is the final output for the structural part of the project. So in the above 1.4 table we have calculated the project productivity considering the value of planned quantity of concrete and actual consumption of the concrete during the 6 months period of the project.

Graph below shows the productivity value in every month till $31^{\text {st }}$ July 2013.

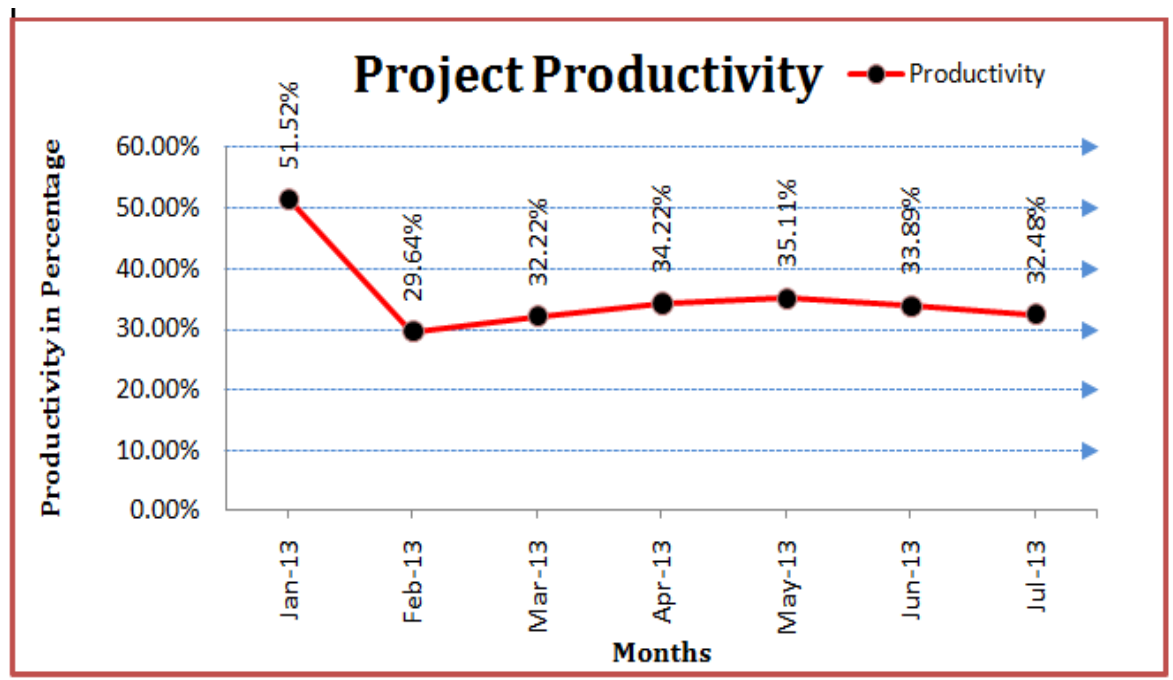

Graph 1.5 Productivity Value

Initially project has a productivity of $51.52 \%$ when requirement of concrete was less but after the month of January 2013 requirements of concrete increase as per initial planning of the project and to fulfill the requirement there were no sufficient resources available so the productivity of the project frequently goes on decreasing till $32.48 \%$ in month of July 2013 as the result 3 months delay has accrue in the total time schedule of the project. To maintain the time schedule of the project and to achieve the productivity substantially improvement for all major activity is required.

\section{Conclusion\& Recommendation}

As project is already delayed by 3 months of its time schedule with productivity of $32.48 \%$ the management has to first maintain its progress as per planned and to keep the project on schedule management has to increase the Percentage of productivity. Following table 1.5 shows that shortfalls in productivity percentage for last seven months. 


\begin{tabular}{|l|l|l|l|l|}
\hline $\begin{array}{l}\text { Month \& } \\
\text { Year }\end{array}$ & $\begin{array}{l}\text { Planned } \\
\text { Cumulative }\end{array}$ & $\begin{array}{l}\text { Executed } \\
\text { Cumulative }\end{array}$ & Difference & $\begin{array}{l}\text { Productivity } \\
\text { in \% }\end{array}$ \\
\hline & A & B & A-B = D & D/A \\
\hline Jan-13 & 1050.00 & 541.00 & 509.00 & $48.48 \%$ \\
\hline Feb-13 & 3568.00 & 897.10 & 2670.90 & $74.86 \%$ \\
\hline Mar-13 & 6299.00 & 1740.27 & 4558.73 & $72.37 \%$ \\
\hline Apr-13 & 8948.00 & 2466.53 & 6481.47 & $72.43 \%$ \\
\hline May-13 & 12018.00 & 3353.63 & 8664.37 & $72.09 \%$ \\
\hline Jun-13 & 15418.00 & 4088.03 & 11329.97 & $73.49 \%$ \\
\hline Jul-13 & 18557.00 & 4699.03 & 13857.97 & $74.68 \%$ \\
\hline
\end{tabular}

Table 1.5 - Shortfalls in Productivity

As productivity of the project is $32.48 \%$ as on month of July 2013 , before increasing the productivity contractor has achieve estimated targeted quantity and to maintain the productivity and to cover up the delay due to low productivity management has to increasethe productivity by $74.68 \%$ with the substantial recommendations given below.

- Appointing more subcontractors/ Agencies is recommended for splitting the work building wise.

- Increasing the shuttering material quantity.

- Storage of reinforcement so that cutting and bending of steel is done in advance.

- Make sure that all the resources and Material are available at site just in time and make funds available.

- Increasing resources/labour and sub-contractors.

- Increasing site working time to cover the delays.

- Approve an alternate concrete Batching Plant.

- Offer incentives to labour \& subcontractors for meeting the targeted production per week/ per month.

- Short out difficulties if any/ disputed/ weekly meeting with clients, consultant.

○ Provide more supervisory staff to control the production.

\section{References}

[1] Arditi, D. and Mochtar, K. (2000) Trends in Productivity Improvement in the US Construction Industry,Journal of Construction Management and economics, Vol. 18

[2] Borcherding, J.D.; Palmeter, S.B., and Jansma, G.L. (1975) Work Force Management Programs for Increased Productivity and Quality Work, EEI Construction Committee Spring Meetings.

[3] Edosomwan, Marcel Dekker, Integrating productivity and quality management, New York, 1987. Page No. 360

[4] Ewe Chye LIM [1996], The Analysis Of Productivity, Loughborough University Singapore. Creative Commons

[5] Goodrum et al. [2002]. The divergence in aggregate and activity estimates of US construction productivity. Construction Management and Economics, 20(5), 415-423.

[6] Huang et al. [2009]. Metrics and Tools for Measuring Construction Productivity: Technical and Empirical Considerations. NIST Spec. Publ. 1101. Gaithersburg, MD: National Institute of Standards and Technology.

[7] Oglesby, C. H., Parker, H. W., and Howell, G. A [1975]. Productivity improvement in construction, McGraw-Hill, New York.

[8] Mr. James D. Whiteside II, PE, Cost Engineering Consultant, ConocoPhillips [2006]. AACE International Transactions 